\title{
PERAN PELAKSANA PENYULUHAN HUKUM KANTOR WILAYAH KEMENTERIAN HUKUM DAN HAM BANTEN DALAM SOSIALISASI BANTUAN HUKUM GRATIS BAGI MASYARAKAT TIDAK MAMPU
}

\author{
Anton Aulawi ${ }^{1}$, Ratu Mimi Darniasih ${ }^{2}$ \\ Universitas Banten Jaya \\ Serang, Indonesia \\ antonaulawi@unbaja.ac.id ${ }^{1,}$ ratu.m52@yahoo.com ${ }^{2}$
}

\begin{abstract}
The purpose of this research was to determine the role of Legal Counselors in the Regional Office of the Banten Ministry of Law and Human Rights in the socialization of free legal aid for the poor. In this research the authors use a methodology with a qualitative approach. In the research to be conducted, researchers will use three data collection techniques, by interview, observation, and documentation. The results of this research are that legal aid regulated by Rule Number 16 of 2011 years concerning Legal Aid, is the state's obligation to provide the rights of every citizen to get legal protection and human rights, especially for the poor. The provision of legal aid as a state obligation to implement the constitutional rights of the poor is to provide funding to legal aid organizations with the State Budget. The state is present to provide legal assistance, one of which is by means of the Regional Office of the Ministry of Law and Human Rights Banten. The method of socialization about free legal assistance to the poor is done by legal counseling activities with direct and indirect methods; firstly, legal counseling is carried out solely by law enforcement officers from the Regional Office of the Ministry of Law and Human Rights Banten. Secondly, legal counseling is carried out by accredited legal aid organizations but with budgets derived from legal aid funds from the state with the authority of budget users from the Ministry of Law and Human Rights.
\end{abstract}

Keywords: free legal assistance

\section{PENDAHULUAN}

Opini tentang hukum masih tebang pilih yaitu hukum tajam ke bawah tetapi tumpul ke atas di Negara kita Indonesia masih ada, seperti kasus yang terjadi pada tahun 2009 misalnya, yaitu kasus pencurian kakao oleh warga Negara tidak mampu yang dipanggil Nenek Minah. Pasifnya negara dalam memberi bantuan hukum kepada masyarakat miskin dapat dilihat dari kasus yang menggemparkan masyarakat pada tahun 2009 lalu "kasus pencurian kakao oleh Nenek Minah”. Nenek Minah seorang perempuan tua yang dituduh mencuri tiga kakao perusahaan perkebunan, mengikuti proses pengadilan tanpa didampingi oleh seorang pengacara dan dia terpaksa mengeluarkan uang sendiri untuk biaya transport dari rumahnya ke pengadilan yang melebihi penghasilannya sehari-hari. Nenek Minah mengaku kepada wartawan bahwa dia tidak didampingi pengacara karena tidak tahu apa pengacara itu Menurut UndangUndang Nomor 16 Tahun 2011 tentang 
Bantuan Hukum, pasal 1 angka 1 dan 2 diseebutkan bahwa Bantuan Hukum adalah jasa hukum yang diberikan oleh Pemberi Bantuan Hukum secara cuma-cuma kepada Penerima Bantuan Hukum, sedangkan Penerima Bantuan Hukum adalah orang atau kelompok orang miskin. Jadi pada intinya bantuan hukum artinya adalah bantuan yang diberikan oleh orang yang mempunyai kompetensi untuk memberikan bantuan hukum bagi masyarakat yang memebutuhkannya, khususnya masyarakat yang tidak mampu untuk melindungi hakhak nya serta untuk mendapatkan perlindungan hukum yang layak. Bantuan hukum dilaksanakan pada saat pemohon bantuan sedang berperkara dengan hukum pada saat proses di pengadilan (litigasi) dan bisa juga pada saat berperkara hukum di luar pengadilan (non litigasi). Jasa bantuan hukum juga yang diberikan oleh pemberi bantuan hukum harus dilakukan oleh Organisasi Bantuan Hukum (OBH) seperti Lembaga bantuan Hukum (LBH) atau organisasi kemasyarakatan lainnya yang memberi layanan bantuan hukum berdasarkan Undang- Undang Nomor 16 Tahun 2011 tentang Bantuan Hukum dimana pemberi bantuan hukum dapat melakukan pendampingan bantuan secara litigasi dan non litigasi. Dengan dikeluarkannya Undang-Undang No. 16
Tahun 2011 tentang Bantuan Hukum ini maka masyarakat yang tidak mampu (miskin) bisa menjadi solusi dan merupakan suatu inovasi dalam pelaksanaan pemberian bantuan hukum, karena bantuan hukum merupakan jasa hukum yang diberikan oleh pemberi bantuan hukum secara cuma-Cuma (gratis) kepada penerima bantuan hukum dalam rangka untuk mewujudkan hak konstitusional terhadap warga Negara yang sesuai dengan prinsip persamaan kedudukan di dalam hukum. Tetapi dalam realitanya masih banyak masyarakat tidak mampu (miskin) tidak atau belum mengetahui akan adanya bantuan hukum cuma-cuma bagi masyarakat miskin, sedangkan masyarakat tersebut tidak mampu untuk membayar jasa seorang advokat (Penasehat Hukum) untuk mendampingi perkaranya baik di pengadilan ataupun di luar pengadilan. Meskipun warga atau masyarakat tersebut mempunyai fakta dan bukti yang dapat dipergunakan untuk membela diri, meringankan atau menunjukkan kebenarannya dalam perkara yang dialaminya tersebut, sehingga perkara mereka pun tidak sampai ke pengadilan. Padahal bantuan hukum merupakan hak warga Negara tidak mampu (miskin) yang dapat diperoleh tanpa bayar (probono). Kerap kali orang miskin karena tidak tahu hak-haknya sebagai tergugat tersangka, atau terdakwa diperlakukan tidak adil atau 
dihambat haknya untuk didampingi Advokat. Hal ini tentu saja sangat merugikan pihak yang menuntut haknya dan yang nantinya di proses di pengadilan. Untuk mencegah terjadinya hal tersebut, dibutuhkan peran organisasi bantuan hukum yang memperjuangkan keadilan dan penegakan hukum seperti LBH yang mendampingi klien atau pihak yang dirugikan haknya, dari masyarakat yang ekonomi atau finansial tidak mampu. Dalam rangka teselenggaranya pemberian bantuan hukum kepada masyarakat tidak mampu sebagai implementasi "Negara hadir" melalui penyaluran bantuan hukum gratis bagi masyarakat miskin maka disinilah peran strategis Kementerian Hukum dan HAM RI dalam penyelenggaraan pemerintahan untuk memberikan bantuan hukum bagi masyarakat miskin. Salah satu peran Kementerian Hukum dan HAM RI melalui kantor wilayahnya di setiap propinsi di Indonesia adalah mensosialisasikan kepada masyarakat tentang program bantuan hukum gratis bagi masyarakat miskin yang diselenggarakan Badan Pembinaan Hukum Nasional (BPHN), salah satunya adalah melelui Kantor Wilayah Kemenkumham Banten (Kanwil Kemenkumham Banten). Kanwil Kemenkumham Banten juga berperan aktif dalam kegiatan sosialisasi bantuan hukum dalam rangka keikutsertaan pemerintah memberikan bantuan hukum gratis bagi masyarakat miskin merupakan upaya untuk memaksimalkan program bantuan hukum gratis bagi masyarakat miskin sebagai pemenuhan akses keadilan bagi masyarakat kurang mampu sebagaimana diatur dalam UU Nomor 16 Tahun 2011. Dalam pemberian bantuan hukum bagi masyarakat miskin terdapat 3 (tiga) pihak terkait, yaitu penerima bantuan hukum (orang miskin), pemberi bantuan hukum (Organisasi Bantuan Hukum) serta penyelenggara bantuan hukum (Kementerian Hukum dan HAM). Melalui kegiatan sosialisasi dapat menjadi sarana penyebarluasan informasi adanya program bantuan hukum gratis kepada masyarakat miskin sehingga terwujud pemerataan pemberian bantuan hukum gartis kepada masyarakat miskin di seluruh wilayah di Indonesia serta memacu tingkat kesadaran hukum masyarakat ke jenjang yang lebih baik lagi atau sering disebut masyarakat sadar hukum.

\section{METODE PENELITIAN}

\section{Tempat dan Waktu Penelitian}

Tempat penelitian dilakukan di Kantor Wilayah Kementerian Hukum dan Hak Asasi Manusia yang bertempat di Jalan Brigjen Syamun No.44 Kel. Kotabaru, Kecamatan Serang, Kota Serang. 
Pelaksanaan penelitian ini direncanakan akan dilaksanakan selama (tiga) bulan yaitu pada bulan Maret s.d Mei 2019.

\section{Metode Penelitian}

Dalam penelitian ini penulis menggunakan metodologi dengan pendekatan kualitatif, dengan maksud untuk dapat mengumpulkan, menyusun, hasil wawancara dengan bagian atau pelaksana penyuluhan hukum dari Kanwil Kemenkumham Banten tentang peran petugas pelaksana penyuluhan hokum Kanwil Kemenkumham Banten dalam sosialisasi bantuan hukum gratis untuk masyarakat tidak mampu (miskin). Metode penelitian kualitatif menurut Sugiyono (2014;9) adalah metode penelitian yang berlandaskan pada filsafat postpositivisme, digunakan untuk meneliti pada kondisi obyek yang alamiah, (sebagai lawannya adalah eksperimen) dimana peneliti adalah sebagai instrument kunci, teknik pengumpulan data dilakukan secara trianggulasi (gabungan), analisis data bersifat induktif/kualitatif, dan hasil penelitian kualitatif lebih menekan makna daripada genelalisasi.

\section{Prosedur Pengumpulan Data}

Suharsimi Arikunto (2006:265), instrument pengumpulan data adalah alat bantu yang dipilih dan digunakan oleh peneliti dalam kegiatannya mengumpulkan data agar kegiatan tersebut menjadi sistematis dan dipermudah olehnya.

Pada penelitian yang akan dilakukan penulis, penulis akan menggunakan tiga tekhnik pengumpulan data yaitu diantaranya teknik wawancara, teknik observasi, dan dokumentasi.

\section{Observasi}

Observasi merupakan teknik pengumpulan data yang mempunyai ciri yang spesifik bila dibandingkan dengan teknik yang lain yaitu wawancara dan kuisioner. Karena observasi tidak selalu dengan obyek manusia tetapi juga obyek-obyek alam yang lain. (Sugiyono, 2014:145). Observasi partisipatif pasif. Dalam penelitian ini, penelitian dengan ke tempat penelitian tetapi tidak ikut terlibat dalam kegiatan di tempat penelitian.

\section{Wawancara}

Wawancara adalah percakapan dengan maksud tertentu, percakapan itu di lakukan oleh dua pihak, yaitu pewawancara (interviewer) yang mengajukan pertanyaan dan terwawancara (interviewee) yang memberikan jawaban atas pertanyaan itu. Moleong (2014:186). Pada penelitian ini teknik wawancara yang digunakan peneliti adalah wawancara mendalam maksudnya peneliti mengajukan beberapa pertanyaan secara mendalam yang berhubungan dengan fokus permasalahan. Sehingga data-data yang dibutuhkan dalam penelitian bisa 
terkumpul secara maksimal sedangkan subjek peneliti dengan teknik Purposive Sampling yakni pengambilan sampel bertujuan, sehingga memenuhi kepentingan peneliti. Mengenai jumlah informan dan responden yang diambil terdiri dari:

\section{Data Narasumber}

\begin{tabular}{llc}
\hline No & Uraian & Jumlah \\
\hline 1. & Kementrian Hukum & 2 Orang \\
& dan Hak Asasi \\
& Manusia & \\
\hline 2. & Organisasi Bantuan & 2 Orang \\
& Hukum & \\
\hline 3 & Masyarakat & 2 Orang \\
& Jumlah & 6 Orang \\
\hline
\end{tabular}

\section{Dokumentasi}

Dokumentasi yaitu "metode yang digunakan untuk mencari data mengenai hal-hal atau variabel yang berupa catatan, transkip, buku, surat kabar, majalah, prasasti, notulen rapat, legger, agenda dan lain sebagainya" (Arikunto, 2006: 236). Metode dokumentasi adalah data pendukung yang digunakan oleh peneliti dalam melakukan kegiatan pencatatan terhadap data-data yang ada di Kanwil Kemenkumham Banten.

Dari ketiga teknik pengumpulan data, penulis merasa ketiga teknik tersebut sesuai jika diaplikasikan dalam pendekatan kualitatif. Langkah awal melakukan wawancara dan observasi di Kanwil Kemenkumham Banten untuk mengetahui bagaimana peran pelaksana penyuluhan hukum Kanwil Kemenkumham Banten dalam sosialisasi bantuan hukum gratis bagi masyarakat tidak mampu (miskin).

\section{Pemeriksaan Keabsahan Data}

Dalam penelitian ini, teknik pemeriksaan keabsahan data yang digunakan yaitu triangulasi. Triangulasi adalah teknik pemeriksaan keabsahan data yang memanfaatkan sesuatu yang lain di luar data itu untuk keperluan pengecekan atau sebagai suatu pembanding terhadap data itu. Teknik triangulasi dapat ditempuh dengan jalan sebagai berikut :

a. Membandingkan data hasil pengamatan dengan hasil wawancara.

b. Membandingkan dengan apa yang dikatakan orang di depan umum dengan yang dikatakan secara pribadi.

c. Membandingkan apa yang dikatakan oleh seseorang sewaktu diteliti dengan sepanjang waktu.

d. Membandingkan keadaan dan perspektif seseorang dengan berbagai pandangan orang seperti orang yang berpendidikan.

e. Membandingkan suatu wawancara dengan suatu dokumen yang berkaitan (Moleong, 2014: 178). 
Berdasarkan pendapat Moleong diatas, maka peneliti melakukan perbandingan data yang telah diperoleh, yaitu data-data sekunder hasil kajian pustaka akan dibandingkan dengan data-data primer yang diperoleh sumber yang berbeda di faktafakta yang ditemui lapangan. Sehingga kebenaran dari data yang diperoleh dapat dipercaya dan meyakinkan.

\section{Analisis Data}

Setelah data terkumpul dari hasil pengamatan data, maka diadakan suatu analisis data untuk mengolah data yang ada. Analisa data adalah "Proses mengorganisasikan dan mengurutkan data ke dalam pola, kategori, dan satuan uraian dasar sehingga dapat ditemukan tema dan ditemukan hipotesis kerja seperti yang disarankan oleh data" (Moleong, 2014: 103). Menurut Milles dan Huberman (1992: 20), tahapan analisis data adalah sebagai berikut :

1. Pengumpulan Data

Pengumpulan data ini dilakukan berkaitan dengan data penelitian yang ada di lapangan yaitu peneliti melakukan wawancara dengan petugas pelaksana penyuluhan hukum Kanwil Kemenkumham Banten, OBH/LBH, dan masyarakat. Adapun langkah langkahnya adalah : b) melakukan penelitian;

c) Observasi di lapangan;

d) mendapatkan hasil wawancara; dan

e) dokumentasi.

2. Reduksi Data

Yaitu memilih hal-hal pokok yang sesuai dengan fokus penelitian. Dimana reduksi data merupakan suatu bentuk analisis yang menajamkan, menggolongkan, mengarahkan, membuang yang tidak perlu dan mengorganisasi. Data-data yang telah direduksi memberikan gambaran yang lebih tajam tentang hasil pengamatan dan mempermudah peneliti untuk mencarinya sewaktu-waktu diperlukan. Reduksi data yang peneliti lakukan antara lain dengan menajamkan hasil penelitian mengenai peran petugas pelaksana penyuluhan hokum Kemenkumham Banten dalam sosialisasi UU No.16 Tahun 2011 tentang Bantuan Hukum untuk meningkatkan pengetahuan dan pemahaman masyarakat tentang adanya program bantuan hokum untuk masyarakat miskin sehingga bisa meningkatkan kesadaran hukum di masyarakat, mengarahkan hasil penelitian sesuai dengan permasalahan peneliti dan membuang data yang tidak perlu. Pada tahap ini peneliti memilih data yang paling tepat yang disederhanakan dan diklasifikasikan atau dasar tema, memadukan data yang tersebar,

a) mengurus surat ijin penelitian; 
menelusuri tema untuk data tambahan, dan membuat simpulan menjadi uraian singkat.

\section{Penyajian Data}

Data-data yang diperoleh peneliti baik data primer maupun data sekunder kemudian dikumpulkan untuk diteliti kembali dengan menggunakan metode editing untuk menjamin data-data yang diperoleh itu dapat dipertanggungjawabkan sesuai kenyataan yang ada, selanjutnya dilakukan pembetulan terhadap data yang keliru, dengan demikian dapat dilakukan penambahan data yang kurang lengkap yang kemudian disusun secara sistematis. Dalam penelitian ini, peneliti menyajikan data tentang peran pelaksana penyuluhan hukum Kanwil Kemenkumham Banten dalam sosialisasi bantuan hukum gratis bagi masyarakat tidak mampu. Data tersebut berasal dari hasil observasi, wawancara dengan pelaksana penyuluhan hukum di Kanwil Kemenkumham Banten serta dokumentasi.

4. Penarikan Kesimpulan atau Verifikasi

Menarik simpulan yaitu suatu kegiatan utuh, simpulan yang diverifikasi selama penelitian berlangsung, simpulan final mungkin tidak muncul sampai pengumpulan data akhir, tergantung pada besarnya kumpulan-kumpulan catatan yang ada di lapangan, penyimpanan dan metode pencarian ulang yang digunakan untuk catatan penelitian.
Keempat komponen tersebut saling mempengaruhi dan terkait. Pertama-tama peneliti melakukan penelitian di lapangan dengan menggunakan wawancara atau observasi yang disebut tahap pengumpulan data penyajian data reduksi data penarikan kesimpulan/verifikasi data karena data yang dikumpulkan banyak maka diadakan reduksi data, setelah direduksi kemudian diadakan sajian data. Selain itu pengumpulan data juga digunakan untuk penyajian data. Apabila ketiga tahapan tersebut selesai dilakukan, maka diambil kesimpulan.

\section{PEMBAHASAN}

Pembahasan hasil penelitian ini akan mendeskripsikan hasil penelitian untuk menjawab rumusan masalah yang telah di bahas pada bab sebelumnya yaitu peran pelaksana penyuluhan hukum Kanwil Kemenkumham Banten dalam sosialisasi bantuan hukum gratis bagi masyarakat tidak mampu/miskin.

Peran Pelaksana Penyuluhan Hukum Kantor Wilayah Kementrian Hukum dan Hak Asasi Manusia Banten dalam Sosialisasi Bantuan Hukum Gratis Bagi Masyarakat Tidak Mampu Bantuan hukum pada pokoknya memiliki arti bantuan hukum yang diberikan oleh para ahli bagi warga masyarakat yang memerlukan untuk mewujudkan hak-haknya serta juga mendapatkan perlindungan 
hukum yang wajar. (IGN. Ridwan Widyadharma: 2010: 26).

Berkaitan dengan status mereka yang miskin, sistem bantuan hukum yang dibangun oleh negara juga tidak berpihak kepada masyarakat miskin yang harusnya menjadi sasaran bantuan hukum. Negara dinilai pasif dalam hal pemberian bantuan hukum bagi kelompok masyarakat miskin ini. Bantuan hukum dikonstruksikan dalam berbagai perundang-undangan hanya berfungsi jika masyarakat berhadapan dengan hukum di pengadilan, bahkan dalam kasus pidana hanya yang diancam hukuman lima tahun atau lebih yang bisa mendapatkan bantuan hukum yang mereka butuhkan tanpa diminta. Negara tidak melihat bahwa dari hari ke hari masyarakat miskin menghadapi pelanggaranpelanggaran hak-hak mereka dan mereka tidak bisa mendapatkan bantuan hukum karena negara tidak memasukkan jenis pelanggaran hak ini sebagai kasus yang bisa mendapatkan bantuan hukum. (Buyung, Adnan Nasution,2007:43).

Pelaksanaan penyuluhan hukum menurut Permenkumham Nomor: M-01.PR.08.10 Tahun 2007 yaitu :

Pelaksana Penyuluhan Hukum dilakukan oleh tenaga fungsional penyuluh hukum dan/atau orang yang mempunyai pengetahuan dan keahlian di bidang hukum dan mampu menyampaikan informasi atau penjelasan tentang materi yang disuluhkan, secara jelas dan benar, kepada masyarakat yang disuluh. Sedangkan pelaksanaan penyuluhan hukum di lingkungan Departemen Hukum dan Hak Asasi Manusia, dikoordinasikan oleh Pusat Penyuluhan Hukum Badan Pembinaan Hukum Nasional.

Badan Pembinaan Hukum Nasional dalam melaksanakan penyuluhan hukum dapat melakukan kerja sama dengan instansi terkait atau organisasi kemasyarakatan di tingkat pusat.

Kanwil Kemenkumham Banten melalui Divisi Pelayanan Hukum dan Pelaksana Penyuluhan Hukum untuk melaksanakan tugasnya yaitu memberikan informasi dan pemahaman kepada masyarakat dalam sosialisasi bantuan hukum gratis bagi masyarakat tidak mampu untuk meningkatkan kesadaran hukum di masyarakat yang menggunakan metode baik secara langsung maupun tidak langsung. Peraturan Menteri Hukum dan HAM RI Nomor : M-01.PR.08.10 Tahun 2007 tentang Perubahan atas Peraturan Menteri Hukum dan Hak Asasi Manusia RI Nomor : M01.PR.08.10 Tahun 2006 tentang Pola Penyuluhan Hukum (selanjutnya disebut Permenkumham Nomor : M-01.PR.08.10 Tahun 2007) menurut Pasal 1 Permenkumham Nomor: M01.PR.08.10 Tahun 2007, disebutkan bahwa arti dari penyuluhan hukum yaitu; 
'Penyuluhan hukum adalah salah satu kegiatan penyebarluasan informasi dan pemahaman terhadap norma hukum dan peraturan perundang-undangan yang berlaku guna mewujudkan dan mengembangkan kesadaran hukum masyarakat sehingga tercipta budaya hukum dalam bentuk tertib dan taat atau patuh terhadap norma hukum dan peraturan perundang-undangan yang berlaku demi tegaknya supremasi hukum',

Tujuan dari kegiatan penyuluhan hukum adalah untuk meningkatkan kesadaran hukum masyarakat (sadarkum) berupa penyampaian dan penjelasan peraturan hukum kepada masyarakat dalam suasana formal maupun informal agar setiap masyarakat mengetahui dan memahami tentang hukum termasuk apa yang menjadi hak, kewajiban dan kedudukannya di mata hukum, mengetahui, memahami, sadar, sekaligus mematuhinya (masyarakat sadarkum). sehingga tercipta sikap dan prilaku berdasarkan hukum (budaya hukum).

Untuk mencapai masyarakat patuh hukum harus tercipta masyarakat sadar hukum terlebih dahulu karena kesadaran hukum masyarakat tidak identik dengan kepatuhan hukum hukum masyarakat itu sendiri. Kepatuhan hukum pada hakikatnya adalah "kesetian" seseorang atau subyek hukum terhadap hukum itu yang diujudkan dalam bentuk prilaku yang nyata, sedang "kesadaran hukum masyarakat" masih bersifat abstrak belum merupakan bentuk prilaku yang nyata yang mengakomodir kehendak hukum itu sendiri.

Menurut Laurensius Arliman S (2015:236) dalam bukunya yang berjudul penegakan hukum dan kesadaran masyarakat penyuluhan hukum dapat dilakukan melalui dua cara : pertama, penyuluhan hukum langsung yaitu kegiatan penyuluhan hukum berhadapan dengan masyarakat yang disuluh, dapat berdialog dan bersambung rasa misalnya : ceramah, diskusi, temu, simulasi dan sebagainya. Kedua, penyuluhan hukum tidak langsung yaitu kegiatan penyuluhan hukum yang di lakukan tidak berhadapan dengan masyarakat yang disuluh, melainkan melalui media/perantara, seperti radio, televisi, video, majalah, surat kabar, film, dan lain sebagainya. Penyuluhan hukum yang tidak langsung dalam bentuk bacaan, terutama ceritera bergambar atau strip yang bersifat heroik akan sangat membantu dalam meningkatkan kesadaran hukum masyarakat. Buku pegangan tentang hak dan kewajiban warga Negara Indonesia, susunan Negara, pancasila dan Undangundang Dasar 1945, pasal-pasal yang penting dalam KUHP, bagaimana caranya memperoleh perlindungan hukum perlu diterbitkan. Pelaksana penyuluhan hukum dari Kanwil Kemenkumham Banten 
dilakukan oleh tenaga fungsional penyuluh hukum dan/atau orang yang mempunyai pengetahuan dan keahlian di bidang hukum dan mampu menyampaikan informasi atau penjelasan tentang materi yang disuluhkan, secara jelas dan benar, kepada masyarakat yang disuluh. Pelaksanaan penyuluhan hukum di lingkungan Divisi Pelayanan Hukum dan Hak Asasi Manusia bidang Pelayanan Hukum, dikoordinasikan oleh Pusat Penyuluhan Hukum Badan Pembinaan Hukum Nasional (BPHN). BPHN dalam melaksanakan penyuluhan hukum dapat melakukan kerja sama dengan instansi terkait atau organisasi kemasyarakatan di tingkat pusat. Berdasarkan Peraturan Menteri Hukum dan Hak Asasi Manusia Nomor 30 tahun 2018 tentang Organisasi dan Tata Kerja Kantor Wilayah, disebutkan:

(1) Penyuluhan Hukum langsung diselenggarakan dalam bentuk :
a. ceramah;
b. diskusi;
c. temu sadar hukum;
d. pameran;
e. simulasi;
f. lomba kadarkum;
g. konsultasi hukum;
h. bantuan hukum; dan/atau
i. dalam bentuk lain.

(2) Penyuluhan Hukum tidak langsung diselenggarakan dalam bentuk :
a. dialog interaktif;
b. wawancara radio;
c. pentas panggung;
d. sandiwara;
e. sinetron;
f. fragmen;
g. film;
h. spanduk;
i. poster;
j. brosur;
k. leaflet;
1. booklet;
m. billboard;
n. surat kabar;
o. majalah;
p. running text;
q. filler; dan/atau
r. dalam bentuk lain.

Penyuluhan hukum langsung dilakukan dengan cara bertahap muka secara langsung antara penyuluh dan yang disuluh sedangkan penyuluhan hukum tidak langsung dilakukan melalui media elektronik dan media cetak. Penyuluhan Hukum langsung atau tidak langsung dapat dilakukan secara terpadu dengan berbagai instansi dan/atau organisasi kemasyarakatan/OBH yang terkait baik mengenai penyelenggaraannya, materi yang disuluhkan, maupun sasaran yang disuluh.

Penyuluhan hukum di masyarakat yang dilakukan oleh pelaksana penyuluhan 
hukum dari Kanwil Kemenkumham Banten bekerjasama $\mathrm{OBH}$ biasanya menggunakan metode secara langsung. Secara langsungnya penyuluhan hukum langsung dapat diselenggarakan dalam bentuk ceramah dan diskusi.

Pelaksana penyuluhan hukum mempunyai tugas atau perannya dalam memberikan edukasi. Karena itu pemerintah khususnya pelaksana penyuluhan hukum mempunyai kewajiban memberikan informasi dan pemahaman. Undang-undang di buat itu harus di berikan sosialisasi kepada masyarakat. Di dalam Undang-undang bahwasannya isi Undang-undang itu ketika sudah disahkan berarti masyarakat itu dianggap tau karena bahwasannya undangundang yang sudah disahkan dan disosialisasikan berarti masyarakat dianggap tau tapi masalahnya apakah informasi tersebut sampai kepada masyarakat lapisan bawahnya, tapi itulah kewajiban pemerintah bukan cuma mengabulkan kewajiban bahwasannya undang-undang itu diundangkan jadi dianggap masyarakat tau tapi diberikan edukasinya jangan sebatas di level tengah. Tapi juga di bawahnya sebarannya merata.

Pelaksana penyuluhan hukum dalam mensosialisasikan Undang-Undang Nomor 16 Tahun 2011, di masyarakat diberikan edukasi oleh LBH. Mengenai bantuan hukum.tersebut hal yang senada dengan tanggapan dari Edi Wahyono, SH. selaku Sub Bidang Penyuluhan Hukum, pada wawancara yang dilaksanakan pada tanggal 2 Mei 2019 di kantor Kanwil Kemenkumham Banten, Narasumber menyatakan bahwa Kanwil Kemenkumham Banten telah mengakreditasi Lembaga Bantuan Hukum (LBH), maka LBH itu yang melaksanakan tapi yang membiayai kegiatan tersebut adalah anggarannya melalui Kanwil Kemenkumham Banten di saat ini di banten ada 17 organisasi bantuan hukum itu di wilayah propinsi Banten sudah melalui verivikasi dan akreditasi dari Kanwil Kemenkumham Banten jadi yang memenuhi syarat untuk melakukan penyuluhan hukum di Masyarakat.

Di waktu yang bersamaan pada wawancara yang dilaksanakan pada tanggal 2 Mei 2019 di kantor Kanwil Kemenkumham Banten, Kurniawan. A, SH, dari Sub Bidang Penyuluhan Hukum pun menyatakan Kanwil Kemenkumham Banten sebagai penyelenggara Undang-Undang 16 Tahun 2011 itu sendiri yang dulunya bantuan hukum itu tersebar di mana-mana. misalnya di kejaksaan pengadilan kepolisian dan lainlain. sekarang terpisah hanya di Kanwil Kemenkumham kalaupun di daerah hanya amanat Undang-Undang Bantuan Hukum hanya mengalokasikan dana kalau bagian 
rekrutmen of file LBH nya itu kita. Dan kita telah memverifikasi dan mengakreditasi 17 organisasi bantuan hukum"di wilayah propinsi Banten. Salah satu Organisasi Bantuan Hukum di wilayah propinsi Banten yang telah terakreditasi oleh Kemenkumham adalah Perkumpulan Lembaga Bantuan Hukum Jatramada atau disingkat PLBH Jatramada. PLBH Jatramada adalah salah satu organisasi bantuan hukum terakreditasi B yang ikut berperan dalam memberikan penyuluhan hukum terkait UU Undang-Undang Nomor 16 Tahun 2011 tentang Bantuan Hukum Undang-Undang Nomor 16 Tahun 2011 tentang Bantuan Hukum di masyarakat di wilayah propinsi Banten.

Sebagaimana hasil wawancara peneliti yang dilaksanakan pada tanggal 10 Mei 2019 di kantor PLBH Jatramada Serang, dengan narasumber yaitu Ketua PLBH Jatramada, Andrie Pratama, SH., yang menyatakan bahwa selama ini PLBH Jatramada telah melaksanakan Program Bantuan Hukum merupakan implementasi dari UndangUndang Nomor 16 tahun 2011 tentang Bantuan Hukum. Perkumpulan Lembaga Bantuan Hukum (PLBH) Jatramada adalah salah satu Organisasi Bantuan Hukum terakreditasi di Provinsi Banten guna pelaksanaan bantuan hukum. Keikutsertaan
Bantuan Hukum dalam bantuan hukum, dimulai pada tanggal 31 Mei 2013 berdasarkan sertifikat Kementrian Hukum Dan Hak Asasi Manusia R.I nomor W.12.HN.03.03-001 dan reakreditasi Keputusan Mentri Hukum Dan Hak Asasi Manusia R.I No.M.HH-01.HN.03.03 Tahun 2016 tentang Lembaga/Organisasi Bantuan Hukum yang Lulus Verifikasi dan Akreditasi Sebagai Pemberi Bantuan Hukum periode tahun 2016 s.d 2018, dan kembali mendapat B setelah reakreditasi tahun 2018 s.d 2020. PLBH Jatramada mendapatkan sertifikat akreditasi sebagai pemberi bantuan hukum dengan kategori peringkat $\mathrm{B}$.

PLBH Jatramada dalam mengemban amanat Undang-Undang No. 16 Tahun 2011 yaitu untuk member bantuan hukum kepada masyarakat miskin secara cuma-cuma (probono) khususnya di wilayah Provinsi Banten, dan berdasarkan Surat Keputusan Kementrian Hukum Dan Hak Asasi Manusia R.I maka telah membagi wilayah kerja masing-masing bagi Organisasi Bantuan Hukum, dan untuk PLBH Jatramada yang berdomisili di Griya Permata Asri C 9 No. 6 Kota Serang. Bantuan hukum tersebut meliputi litigasi dan non litigasi, bentuk dari bantuan hukum non litigasi salah satunya adalah penyuluhan hukum dan pemberdayaan hukum di 
masyarakat tidak mampu. Bantuan Hukum adalah jasa hukum yg diberikan oleh pemberi bantuan hukum $(\mathrm{OBH})$ secara cuma-cuma kepada penerima bankum. Bantuan Hukum yang diberikan meliputi maslah hukum Pidana, Perdata dan TataUsaha Negara, baik secara litigasi maupun non litigasi. Menurut Andrie Pratama SH, program bantuan hukum gratis yang telah dilaksanakan oleh PLBH Jatramada adalah : Bantuan Hukum Litigasi meliputi:
a. Kasus pidana
b. Kasus perdata,
c. Kasus tata usaha Negara sedangkan

Bantuan Hukum Non Litigasi meliputi:
a. Penyuluhan hukum;
b. Konsultasi hukum;
c. Investigasi perkara, baik secara elektronik maupun nonelektronik;
d. Penelitian hukum;
e. Mediasi;
f. Negosiasi;
g. Pemberdayaan masyarakat;
h. Pendampingan di luar pengadilan; dan / atau

i. Drafting dokumen hukum.

Hal serupa disampaikan oleh Sudrajat, SH, MH sekretaris PLBH jatramada pada wawancara yang dilaksanakan pada tanggal 12 Mei 2019 di kantor PLBH Jatramada Serang, Narasumber menyampaikan bahwa
PLBH Jatramada telah melakukan penyuluhan hukum dalam rangka Sosialisasi Undang-Undang No. 16 Tahun 2011 tentang bantuan hukum untuk orang miskin di beberapa tempat di wilayah propinsi Banten yaitu Rutan Serang, Rutan Pandeglang, Rutan Lebak, Rutan Tangerang dan beberapa desa di wilayah propinsi Banten diantaranya Kelurahan Pasuluhan dan Pematang Kecamatan Walantaka Kota Serang (tahun 2015) Desa Pematang Kecamatan Kragilan Kabupaten Serang (tahun 2016), Desa Baru Kecamatan Pamarayan Kabupaten Serang (tahun 2017) dan beberapa desa di wilayah Kabupaten Pandeglang pada tahun 2018 dan 2019, sebagian kegiatan penyuluhan hukum tersebut dilaksanakan bersama-sama dengan Petugas Penyuluhan Hukum dari Kanwil Kemenkumham Banten. Dan kegiatan tersebut biaya operasionalnya menggunakan anggaran Negara untuk bantuan hukum melalui kuasa pengguna anggaran Kanwil Kemenkumham Banten.

Berdasarkan Peraturan Menteri Hukum dan HAM RI Nomor : M-01.PR.08.10 Tahun 2007 tentang Perubahan atas Peraturan Menteri Hukum dan Hak Asasi Manusia RI Nomor : M01.PR.08.10 Tahun 2006 tentang Pola Penyuluhan Hukum (selanjutnya disebut Permenkumham Nomor : M01.PR.08.10 Tahun 2007) menurut Pasal 1 
Permenkumham Nomor: M-01.PR.08.10 Tahun 2007, Kesadaran Hukum Masyarakat adalah nilai yang hidup dalam masyarakat dalam bentuk pemahaman dan ketaatan atau kepatuhan masyarakat terhadap norma hukum dan peraturan perundang-undangan yang berlaku. Kesadaran hukum masyarakat khususnya masyarakat miskin/tidak mampu dalam memahami UU No 16 Tahun 2011 dan program bantuan hukum gratis yang diselenggarakan oleh Pemerintah melalui Kementrian Hukum dan HAM yang bermitra dengan advokat dan organisasi bantuan hukum harus diketahui oleh masyarakat miskin supaya keadilan itu dapat dinikmati oleh semua lapisan masyarakat sebagaimana yang diamanatkan Pasal 27 dan 28 D UUD 1945,

"Segala warga negara bersamaan kedudukannya di dalam hukum dan pemerintahan dan wajib menjunjung hukum dan pemerintahan itu dengan tidak ada kecualinya.

"Setiap orang berhak atas pengakuan, jaminan, perlindungan, dan kepastian hukum yang adil serta perlakuan yang sama di hadapan hukum."

\section{KESIMPULAN}

Berdasarkan hasil penelitian dan pembahasan, maka dapat di ambil kesimpulan bahwa Peran Pelaksana Penyuluhan Hukum Kantor Wilayah Kementerian Hukum dan HAM Banten dalam sosialisasi bantuan hukum gratis bagi masyarakat tidak mampu di wilayah propinsi Banten sudah dilaksanakan sesuai tugas dan fungsi nya berdasarkan Peraturan Mentri Hukum dan HAM No.30 Tahun 2018 tentang Organisasi dan Tata Kerja Kanwil Kemenkumham. Metode sosialisasi bantuan hukum gratis untuk masyarakat miskin tersebut dilakukan melalui kegiatan penyuluhan hukum dengan metode langsung dan tidak langsung. Dalam kegiatan penyuluhan hukum oleh Kanwil Kemenkumham Banten dalam rangka sosialisasi undang-undang dan program bantuan hukum gratis bagi masyarakat tidak mampu (miskin) di wilayah propinsi Banten biasanya dilakukan dengan dua cara; yaitu pertama penyuluhan hukum dilakukan sendiri oleh petugas pelaksana penyuluhan hukum dari Kanwil Kemenkumham Banten. Kedua penyuluhan hukum dilakukan bersama-sama oleh petugas pelaksana penyuluhan hukum dari Kanwil Kemenkumham Banten dengan organisasi bantuan hukum terakreditasi atau hanya melalui organisasi bantuan hukum terakreditasi tetapi dengan anggaran yang berasal dari dana bantuan hukum dari Negara (APBN) dengan kuasa pengguna anggaran dari Kementrian Hukum dan HAM. 


\section{DAFTAR PUSTAKA}

\section{a. Buku:}

Arikunto, Suharsimi. (2006). Prosedur Penelitian Suatu Pendekatan Praktik. Jakarta: PT Rineka Cipta

Buyung, Adnan Nasution, (2007), Bantuan Hukum Di Indonesia, , Jakarta:LP3ES.

IGN. Ridwan Widyadharma, (2010), Profesional Hukum dalam Pemberian Bantuan Hukum, Semarang: Badan Penerbit Universitas Diponegoro, Semarang.

Lauriensius Arliman S. (2015). Penegakan Hukum dan Kesadaran Masyarakat: Ed.1, Cet.1. Yogyakarta : Deepublish.

Miles, M.B \& huberman, A.M. (1992). Analisa data kualitaif. (penerjemah: Rohid, R.T). UI Press. Jakarta

Moleong, L. (2014). Metodologi Penelitian Kualitatif. Bandung: PT Remaja Rosdakarya.

Sugiono.(2014). Metode Penelitian Kuantitatif Kualitatif dan $R \& D$ : Cet.21. Bandung:Alfabeta.

\section{b. Peraturan Perundang-undangan:}

Peraturan Menteri Hukum dan Hak Asasi Manusia Republik Indonesia Nomor : M.01-Pr.08.10 Tahun 2006 Tentang Pola Penyuluhan Hukum

Peraturan Menteri Hukum dan Hak Asasi Manusia Republik Indonesia Nomor M-01.PR.07.10 Tahun 2005 tentang Organisasi dan Tata Kerja Kantor Wilayah Departemen Hukum dan Hak Asasi Manusia Republik Indonesia.

Peraturan Menteri Hukum dan Hak Asasi Manusia Republik Indonesia Nomor: $\quad$ M.HH-05.OT.01.01 TAHUN 2010 tentang Organisasi dan Tata Kerja Kementerian Hukum dan Hak Asasi Manusia Republik Indonesia.

Undang-undang Republik Indonesia Nomor 16 Tahun 2011 Tentang Bantuan Hukum. 